\title{
Synthesis and biochemical studies of 17-substituted androst-3-enes and 3,4-epoxyandrostanes as aromatase inhibitors
}

\author{
Margarida M.D.S. Cepa ${ }^{a, b}$, Elisiário J. Tavares da Silva ${ }^{c}$, Georgina Correia-da-Silva ${ }^{a, b}$, \\ Fernanda M.F. Roleira ${ }^{c, *}$, Natércia A.A. Teixeira ${ }^{a, b}$ \\ a Biochemistry Laboratory, Faculty of Pharmacy, University of Porto, Rua Aníbal Cunha 164, 4099-030 Porto, Portugal \\ b Institute for Molecular and Cellular Biology, 4150-180 Porto, Portugal \\ c Center of Pharmaceutical Studies, Pharmaceutical Chemistry Laboratory, Faculty of Pharmacy, \\ University of Coimbra, 3000-295 Coimbra, Portugal
}

\section{A R T I C L E I N F O}

Article history:

Received 30 April 2008

Received in revised form 2 July 2008

Accepted 9 July 2008

Published on line 17 July 2008

\section{Keywords:}

Aromatase inhibitor

Synthetic androstanes

Structure-function study

Breast cancer

\begin{abstract}
A B S T R A C T
A series of $5 \alpha$-androst-3-enes and $3 \alpha, 4 \alpha$-epoxy- $5 \alpha$-androstanes were synthesized and tested for their abilities to inhibit aromatase in human placental microsomes. In these series the original C-17 carbonyl group was replaced by hydroxyl, acetyl and hydroxyimine groups. Inhibition kinetic analysis on the most potent steroid of these series revealed that it inhibits the enzyme in a competitive manner $\left(\mathrm{IC}_{50}=6.5 \mu \mathrm{M}\right)$. The achieved data pointed out the importance of the C-17 carbonyl group in the D-ring of the studied steroids as a structural feature required to reach maximum aromatase inhibitory activity. Further, at least one carbonyl group (C-3 or C-17) seems to be essential to effective aromatase inhibition.
\end{abstract}

(c) 2008 Elsevier Inc. All rights reserved.

\section{Introduction}

Hormone-dependent breast tumors require estrogens for their growth [1]. Two main approaches have been applied to block estrogen action. One acts directly at the estrogen receptor, by means of selective estrogen receptor modulators (SERMs) and other targets aromatase, a cytochrome P-450 enzyme (CYP19), responsible for estrogen biosynthesis [2]. In breast cancer, intratumoral aromatase is the source for local estrogen production and inhibition of this enzyme is an important approach for reducing tumor growth. Tamoxifen, the most well-known SERM, has been considered the gold standard of endocrine therapy in hormone-dependent breast cancer. Nowadays, it is being taken over by aromatase inhibitors (AIs) in postmenopausal women, due to their superior efficacy and favorable safety profile [3-6]. The potent and selective third-generation AIs are being used as endocrine therapy in postmenopausal patients failing anti-estrogen therapy alone or multiple hormonal therapies. There are two classes of AIs, steroidal and nonsteroidal compounds [7-9], which cause potent estrogen suppression $[5,10]$. The non-steroidal AIs are mostly azole type compounds such as the clinically used anastrazole and letrozole, which compete with the substrate for binding to the enzyme active site. Steroidal AIs, as exemestane and formestane (Fig. 1), mimic the natural substrate androstenedione and are converted by the enzyme in reactive intermediates, which bind irreversibly to the enzyme active site, resulting in inactivation of aromatase.

\footnotetext{
* Corresponding author. Tel.: +351 239859992; fax: +351 239827126.

E-mail address: froleira@ff.uc.pt (F.M.F. Roleira).
} 


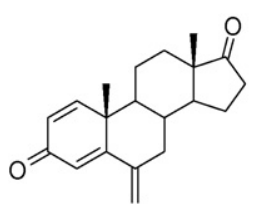

Exemestane

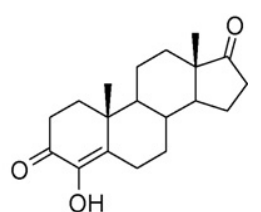

Formestane
Fig. 1 - Steroidal aromatase inhibitors.

Despite the success of the third-generation steroidal and nonsteroidal AIs, they still have some major side effects, such as the increase of bone loss. For this reason, it is important to search for other potent and specific molecules with lower side effects. Moreover, understanding the interactions of new inhibitors with aromatase lead to new important information for quantitative structure-activity relationships (QSAR) that might help to elucidate the 3D structure of the enzyme. The present study may contribute for these goals.

Recently, a new series of steroids obtained from modifications in the A- and D-rings of the aromatase substrate, androstenedione, were designed, synthesized and evaluated for aromatase inhibitory activity by our group [11]. In that work, we have studied three main structural features considered important for the drug-enzyme interaction, namely the planarity of the A-ring, the $5 \alpha$-stereochemistry and the integrity of the cyclopentanone D-ring. In the present work, we have specially focused on the effect of some refined modifications in the original C-17 carbonyl group in the Dring of $5 \alpha$-androst-3-enes and $3 \alpha, 4 \alpha$-epoxy- $5 \alpha$-androstanes in enzyme inhibition. In fact, some authors pointed out that modifications on C-17 carbonyl group, such as reduction to a $17 \beta$-hydroxyl group, or deoxygenation to form a methylene group in analogs of androsta-1,4-diene-3,17-dione causes only modest decreases in apparent affinity to aromatase [12]. On the other hand, other authors referred that a 17carbonyl group is necessary for a tight binding to aromatase of the 3-deoxyandrost-4-ene steroid analogs [13]. We are interested to know whether the substitution of the C-17 carbonyl group in $5 \alpha$-androst-3-enes and $3 \alpha, 4 \alpha$-epoxy- $5 \alpha$-androstanes can affect their aromatase inhibitory activity. For this reason, two steroids, the $5 \alpha$-androst-3-en-17-one $3 a$ and the $3 \alpha, 4 \alpha$-epoxy- $5 \alpha$-androstan-17-one $4 \mathrm{a}$ (Scheme 1 ), that have previously shown to be potent aromatase inhibitors in placental microsomes [11], are used as lead compounds. From them, two series of $\mathrm{C}-17$ derivatives bearing hydroxyl ( $3 \mathrm{~b}$, $4 b)$, acetyl $(3 c, 4 c)$ and hydroxyimine groups (3d, 4d), were synthesized and their aromatase inhibitory activity evaluated.

\section{Experimental}

\subsection{Chemistry}

Melting points (Mps) were determined on a Reichert Thermopan hot block apparatus and were not corrected. IR spectra were recorded on a Jasco 420FT/IR Spectrometer. The ${ }^{1} \mathrm{H}$ NMR spectra were recorded at $500 \mathrm{MHz}$, on a Varian Unity 500 and at $300 \mathrm{MHz}$ on a Bruker-AC 300 spectrometers. The ${ }^{13} \mathrm{C}$ NMR spectra were recorded at $125 \mathrm{MHz}$ on a Varian Unity 500 and at $75.6 \mathrm{MHz}$ on a Bruker-AC 300 spectrometers. Chemical shifts were recorded in $\delta$ values in parts per million (ppm) downfield from tetramethylsilane as an internal standard. All $J$-values are given in Hz. Mass spectra EIMS and ESI were obtained with mass spectrometers VG AutoSpecQ EI and QTOF2 Micromass UK. Analytical samples for physicochemical and biological assays were obtained by column chromatography (silica gel 60 with petroleum ether $40-60^{\circ} \mathrm{C}$ and ethyl acetate mixtures). Reagents and solvents were used as obtained from the suppliers without further purification. Yields have not been optimized.

Compound 2 was prepared by Jones oxidation of testosterone [14]. Compounds $3 \mathrm{a}$ and $4 \mathrm{a}$ were prepared as described [11].

\section{2. $5 \alpha$-Androst-3-en-17 $\beta$-ol (3b)}

To a solution of $5 \alpha$-androst-3-en-17-one $3 \mathrm{a}(0.4 \mathrm{~g}, 1.47 \mathrm{mmol})$ in methanol $(40 \mathrm{ml})$, sodium borohydride $(0.2 \mathrm{~g}, 5.2 \mathrm{mmol})$ was added and the reaction mixture was stirred at room temperature $\left(23^{\circ} \mathrm{C}\right)$. A white precipitate was formed after $15-20 \mathrm{~min}$ of stirring and after $1 \mathrm{~h}$ of reaction TLC control showed that all the starting material has been consumed. The reaction was then worked-up by methanol evaporation followed by dissolution of the residue obtained with diethyl ether $(150 \mathrm{ml})$. The organic layer was then washed with water $(3 \times 100 \mathrm{ml})$ dried, over anhydrous $\mathrm{MgSO}_{4}$, filtered and concentrated to dryness giving the pure compound $3 \mathrm{~b}$ as a white solid $(0.359 \mathrm{~g}$, $89 \%$ yield). $\mathrm{Mp}_{\text {(cyclohexane) }} 147-150^{\circ} \mathrm{C}$ (lit [15] $147-150^{\circ} \mathrm{C}$ ); IR $v_{\max }(\mathrm{KBr}) \mathrm{cm}^{-1}$ : $3215(\mathrm{O}-\mathrm{H}), 3013(=\mathrm{C}-\mathrm{H}) ;{ }^{1} \mathrm{H}$ NMR $(300 \mathrm{MHz}$, DMSO- $\left.d_{6}\right) \delta: 0.63\left(3 \mathrm{H}, \mathrm{s}, 18-\mathrm{H}_{3}\right), 0.73\left(3 \mathrm{H}, \mathrm{s}, 19-\mathrm{H}_{3}\right), 3.42(1 \mathrm{H}$, ddd, $\left.J_{17 \alpha, 16 \beta}=8.5, J_{17 \alpha, 16 \alpha}=8.5, J_{17 \alpha, 17 \beta O H}=4.7,17 \alpha-\mathrm{H}\right), 4.43(1 \mathrm{H}$, $\left.\mathrm{d}, J_{17 \alpha, 17 \beta O H}=4.7,17 \beta-\mathrm{OH}\right), 5.25\left(1 \mathrm{H}, \mathrm{ddd}, J_{4,3}=9.7, J_{4,5 \alpha}=4.5\right.$, $\left.J_{4,2 \alpha}=2.5,4-\mathrm{H}\right), 5.52\left(1 \mathrm{H}, \mathrm{ddd}, J_{3,4}=9.7, J_{3,2 \beta}=6.3, J_{3,2 \alpha}=3.1,3-\mathrm{H}\right)$; ${ }^{13} \mathrm{C}$ NMR (75.6 MHz, DMSO- $d_{6}$ ) $\delta: 11.4$ (C-19), 11.7 (C-18), 20.3, 23.0, 23.1, 26.9, 29.8, 31.2, 33.6, 34.5, 35.2, 36.6, 42.7, 45.4 (C-5), 50.6, 53.0, 80.0 (C-17), 125.2 (C-3), 131.1 (C-4); EIMS m/z $274\left(\mathrm{M}^{+}\right.$, $85 \%)$.

\section{3. $3 \alpha, 4 \alpha$-Epoxy-5 $\alpha$-androstan-17 $\beta$-ol (4b)}

To a solution of $5 \alpha$-androst-3-en- $17 \beta$-ol $3 b$ ( $300 \mathrm{mg}, 1.09 \mathrm{mmol}$ ) in methylene chloride $(5.0 \mathrm{ml})$, a solution of performic acid ( $0.15 \mathrm{ml}$ of $\mathrm{HCOOH} 98-100 \%$ and $0.4 \mathrm{ml}$ of $\mathrm{H}_{2} \mathrm{O}_{2} 35 \%$ ) was added and the reaction mixture was stirred overnight until total transformation of the starting material. The reaction was worked-up by addition of methylene chloride $(150 \mathrm{ml})$ and the organic layer was washed with $10 \% \mathrm{NaHCO}_{3}(100 \mathrm{ml})$ followed by water $(4 \times 100 \mathrm{ml})$. After drying the organic layer over anhydrous $\mathrm{MgSO}_{4}$, filtration and solvent evaporation to dryness gave the pure $4 \mathrm{~b}$ as a white solid (293 mg, 93\%). $\mathrm{Mp}_{\text {(ethylacetate } / \text {-hexane) }} 151-153^{\circ} \mathrm{C}$; IR $v_{\max }(\mathrm{KBr}) \mathrm{cm}^{-1}: 3303$ $(\mathrm{O}-\mathrm{H}) ;{ }^{1} \mathrm{H}$ NMR $\left(300 \mathrm{MHz}, \mathrm{DMSO}-d_{6}\right) \delta: 0.61\left(3 \mathrm{H}, \mathrm{s}, 18-\mathrm{H}_{3}\right)$, $0.72\left(3 \mathrm{H}, \mathrm{s}, 19-\mathrm{H}_{3}\right), 2.59\left(1 \mathrm{H}, \mathrm{d}, J_{4 \beta, 5 \alpha}=3.8,4 \beta-\mathrm{H}\right), 3.08(1 \mathrm{H}$, $\left.\mathrm{dd}, J_{3 \beta, 2 \alpha}=3.0, J_{3 \beta, 2 \beta}=3.0,3 \beta-\mathrm{H}\right), 3.41\left(1 \mathrm{H}, \mathrm{ddd}, J_{17 \alpha, 16 \beta}=8.1\right.$, $\left.J_{17 \alpha, 16 \alpha}=8.1, J_{17 \alpha, 17 \beta O H}=4.5,17 \alpha-H\right), 4.42\left(1 \mathrm{H}, \mathrm{d}, J_{17 \alpha, 17 \beta O H}=4.5\right.$, $17 \beta-\mathrm{OH}) ;{ }^{13} \mathrm{C}$ NMR $\left(75.6 \mathrm{MHz}\right.$, DMSO- $\left.d_{6}\right) \delta: 11.4$ (C-18), 13.1 (C19), 20.5, 20.9, 23.0, 26.2, 29.8, 30.1, 31.1, 33.7, 35.0, 36.5, 42.6, 


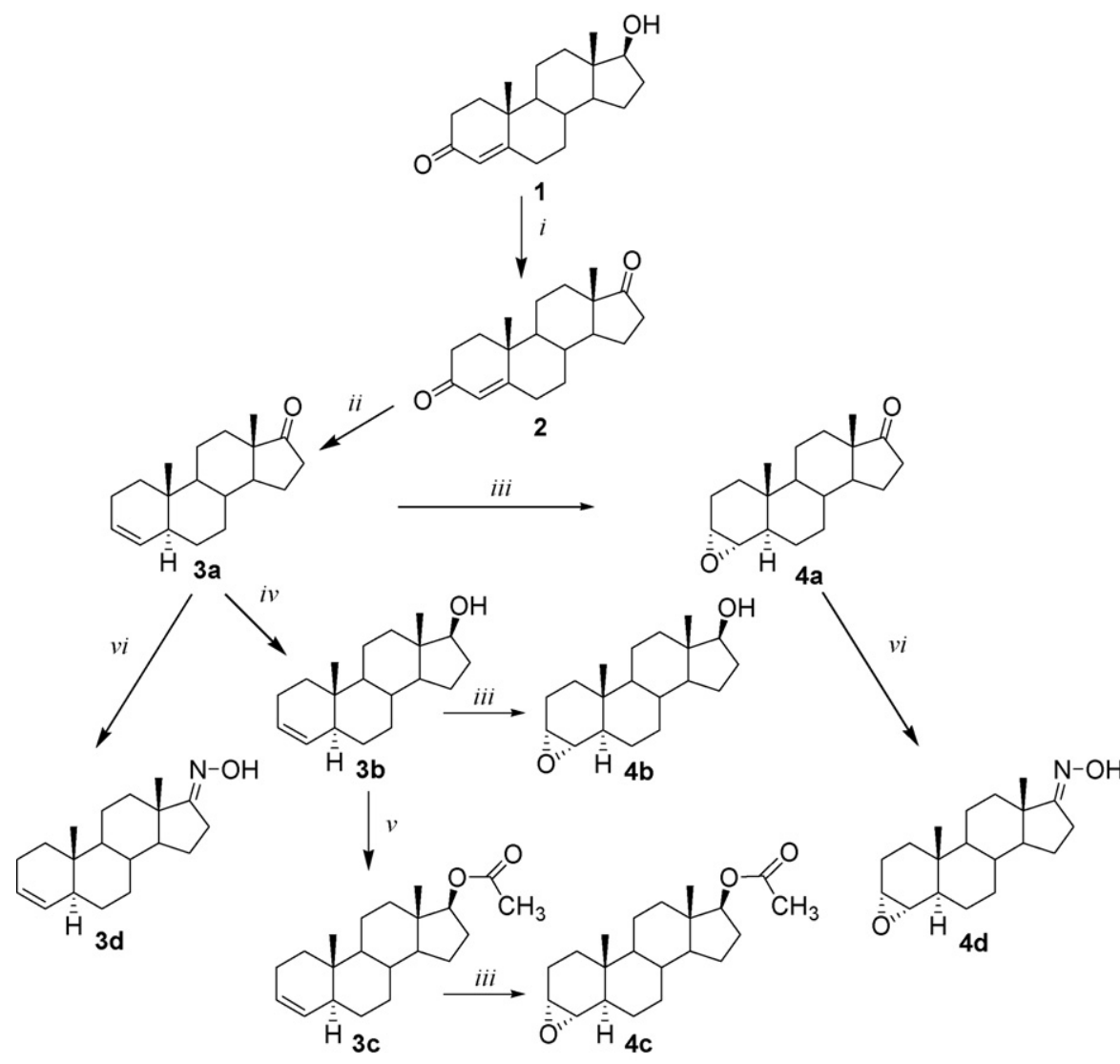

Scheme 1 - Synthesis of aromatase inhibitors from testosterone. Reagents and conditions: (i) $\mathrm{CrO}_{3}, \mathrm{H}_{2} \mathrm{SO}_{4}, \mathrm{acetone} \mathrm{RT}_{\text {, }}$ $5 \mathrm{~min}$ (98\%); (ii) $\mathrm{CH}_{3} \mathrm{CO}_{2} \mathrm{H}$, Zn dust, $118^{\circ} \mathrm{C}, 15 \mathrm{~min}$ (60\%); (iii) $\mathrm{H}_{2} \mathrm{O}_{2}, \mathrm{HCO}_{2} \mathrm{H}$, dichloromethane, RT, overnight (92-96\%); (iv) $\mathrm{NaBH}_{4}$, methanol RT, $1 \mathrm{~h}$ (89\%); (v) $\left(\mathrm{CH}_{3} \mathrm{CO}\right)_{2} \mathrm{O}$, pyridine, RT, overnight (95\%); (vi) $\mathrm{NH}_{2} \mathrm{OH} . \mathrm{HCl}, \mathrm{CH}_{3} \mathrm{CO}_{2} \mathrm{Na} \cdot 3 \mathrm{H}_{2} \mathrm{O}, \mathrm{methanol}$ $40^{\circ} \mathrm{C}, 5 \mathrm{~h}(54-84 \%)$.

46.5, 50.4, 51.0, 52.3 (C-4), 54.6 (C-3), 80.0 (C-17); EIMS m/z 290 $\left(\mathrm{M}^{+}, 100 \%\right)$.

\section{4. $5 \alpha$-Androst-3-en-17 $\beta$-yl acetate (3c)}

To a solution of $5 \alpha$-androst-3-en- $17 \beta-o l$ $3 b \quad(122.5 \mathrm{mg}$, $0.45 \mathrm{mmol})$ in dry pyridine $(3.0 \mathrm{ml})$, acetic anhydride $(0.5 \mathrm{ml}$, $5.29 \mathrm{mmol}$ ) was added and the reaction was stirred overnight at room temperature until all the starting material has been consumed. Methylene chloride $(100 \mathrm{ml})$ was added and the organic layer was washed with $10 \% \mathrm{NaHCO}_{3}(2 \times 100 \mathrm{ml}), 10 \%$ $\mathrm{HCl}(2 \times 100 \mathrm{ml})$ and water $(2 \times 100 \mathrm{ml})$, dried over anhydrous $\mathrm{MgSO}_{4}$, filtered and concentrated to dryness, giving $134.9 \mathrm{mg}$ (95\%) of the pure $3 \mathrm{c}$ as a white solid. $\mathrm{Mp}_{\text {(ethanol) }} 116-119^{\circ} \mathrm{C}$ (lit [15] $\left.116-118^{\circ} \mathrm{C}\right)$; IR $v_{\max }(\mathrm{KBr}) \mathrm{cm}^{-1}: 3015(=\mathrm{C}-\mathrm{H}), 1733$ $(\mathrm{C}=\mathrm{O}) ;{ }^{1} \mathrm{H} \mathrm{NMR}\left(300 \mathrm{MHz}, \mathrm{CDCl}_{3}\right) \delta: 0.77\left(3 \mathrm{H}, \mathrm{s}, 18-\mathrm{H}_{3}\right)^{*}, 0.79$ $\left(3 \mathrm{H}, \mathrm{s}, 19-\mathrm{H}_{3}\right)^{*}, 2.03\left(3 \mathrm{H}, \mathrm{s}, \mathrm{CH}_{3} \mathrm{COO}\right), 4.59\left(1 \mathrm{H}, \mathrm{dd}, J_{17 \alpha, 16 \alpha}=7.9\right.$, $\left.J_{17 \alpha, 16 \beta}=7.9,17 \alpha-\mathrm{H}\right), 5.27\left(1 \mathrm{H}, \mathrm{ddd}, J_{4,3}=9.8, J_{4,5 \alpha}=4.5, J_{4,2 \alpha}=2.5\right.$, $4-\mathrm{H}), 5.54\left(1 \mathrm{H}\right.$, ddd, $\left.J_{3,4}=9.8, J_{3,2 \beta}=6.3, J_{3,2 \alpha}=3.2,3-\mathrm{H}\right) ;{ }^{13} \mathrm{C} \mathrm{NMR}$ $\left(75.6 \mathrm{MHz}, \mathrm{DMSO}-\mathrm{d}_{6}\right) \delta$ : $11.8(\mathrm{C}-19)^{* *}, 12.2(\mathrm{C}-18)^{* *}, 20.5,21.1$, 23.4, 23.5, 27.2, 27.5, 31.5, 34.1, 34.9, 35.3, 36.9, 42.7, 45.8 (C-5), 50.7, 53.3, 82.9 (C-17), 125.4 (C-3), 131.2 (C-4), 171.2 (C=O); EIMS $\mathrm{m} / \mathrm{z} 316\left(\mathrm{M}^{+}, 100 \%\right)$.

$\left(^{*}\right),\left(^{* *}\right)$ Signals may be interchangeable.

\section{5. $3 \alpha, 4 \alpha$-Epoxy-5 $\alpha$-androstan-17 $\beta$-yl acetate (4c)}

To a solution of $5 \alpha$-androst-3-en- $17 \beta$-yl acetate $3 c$ (308 mg, $0.97 \mathrm{mmol})$ in methylene chloride $(5.0 \mathrm{ml})$, a solution of performic acid ( $0.15 \mathrm{ml}$ of $\mathrm{HCOOH} 98-100 \%$ and $0.4 \mathrm{ml}$ of $\mathrm{H}_{2} \mathrm{O}_{2} 35 \%$ ) was added and the reaction stirred overnight until complete transformation of the starting material. Methylene chloride $(150 \mathrm{ml})$ was added and the organic layer was washed with $10 \% \mathrm{NaHCO}_{3}(2 \times 100 \mathrm{ml})$, water $(4 \times 100 \mathrm{ml})$ and dried over anhydrous $\mathrm{MgSO}_{4}$. After filtration and solvent evaporation to dryness, $296 \mathrm{mg}$ (92\%) of the pure compound 4c was obtained as a white solid. $\mathrm{Mp}_{\text {(ethylacetate } / n \text {-hexane) }} 188-190^{\circ} \mathrm{C}$; IR $v_{\max }(\mathrm{KBr})$ $\mathrm{cm}^{-1}: 1732(\mathrm{C}=\mathrm{O}) ;{ }^{1} \mathrm{H}$ NMR $\left(300 \mathrm{MHz}, \mathrm{CDCl}_{3}\right) \delta: 0.77(3 \mathrm{H}, \mathrm{s}, 18$ $\left.\mathrm{H}_{3}\right)^{*}, 0.78\left(3 \mathrm{H}, \mathrm{s}, 19-\mathrm{H}_{3}\right)^{*}, 2.03\left(3 \mathrm{H}, \mathrm{s}, \mathrm{CH}_{3} \mathrm{COO}\right), 2.69(1 \mathrm{H}, \mathrm{d}$, $\left.J_{4 \beta, 5 \alpha}=3.9,4 \beta-\mathrm{H}\right), 3.16\left(1 \mathrm{H}, \mathrm{dd}, J_{3 \beta, 2 \alpha}=3.0, J_{3 \beta, 2 \beta}=3.0,3 \beta-\mathrm{H}\right), 4.58$ $\left(1 \mathrm{H}, \mathrm{dd}, J_{17 \alpha, 16 \alpha}=9.0, J_{17 \alpha, 16 \beta}=7.8,17 \alpha-\mathrm{H}\right) ;{ }^{13} \mathrm{C}$ NMR $(75.6 \mathrm{MHz}$, DMSO- $\left.d_{6}\right) \delta: 12.1$ (C-19), 13.4 (C-18), 20.7, 21.2, 21.3, 23.4, 26.6, $27.5,30.4,31.4,34.1,35.1,36.8,42.6,46.7,50.5,52.1^{* *} 52.5(\mathrm{C}-4)^{* *}$, 55.8 (C-3), 82.7 (C-17); 171.2 (C=O); EIMS m/z $332\left(\mathrm{M}^{+}, 87 \%\right)$.

$\left.\left({ }^{*}\right),{ }^{* *}\right)$ Signals may be interchangeable.

\section{6. $5 \alpha$-Androst-3-en-17-one oxime (3d)}

To a solution of $5 \alpha$-androst-3-en-17-one $3 \mathrm{a}$ (150 mg, $0.55 \mathrm{mmol})$ in methanol $(7.0 \mathrm{ml})$, hydroxylamine hydrochloride 
(49.2 mg, $0.7 \mathrm{mmol}$ ) and $\mathrm{CH}_{3} \mathrm{COONa} \cdot 3 \mathrm{H}_{2} \mathrm{O}(90 \mathrm{mg}, 0.66 \mathrm{mmol})$ were added. The reaction was stirred at $40^{\circ} \mathrm{C}$ for $5 \mathrm{~h}$ until all the starting material has been consumed. After water addition $(50 \mathrm{ml})$, the methanol was evaporated and the aqueous phase was extracted with methylene chloride $(100 \mathrm{ml})$. The organic layer was then washed with $\mathrm{NaHCO}_{3} \quad 10 \%$ $(2 \times 50 \mathrm{ml})$, water $(3 \times 100 \mathrm{ml})$, dried over $\mathrm{MgSO}_{4}$, filtered and evaporated to dryness yielding $133.7 \mathrm{mg}(84 \%)$ of compound 3d. $\mathrm{Mp}_{\left.\text {(cyclohexane or petroleum ether } 40-60^{\circ} \mathrm{C}\right)} \quad 159-161^{\circ} \mathrm{C}$; IR $\nu_{\max }$ $(\mathrm{KBr}) \mathrm{cm}^{-1}$ : $3281(\mathrm{O}-\mathrm{H}), 3013(=\mathrm{C}-\mathrm{H}) ;{ }^{1} \mathrm{H}$ NMR $(300 \mathrm{MHz}$, DMSO-d $\left.\mathrm{d}_{6}\right) \delta: 0.75\left(3 \mathrm{H}, \mathrm{s}, 19-\mathrm{H}_{3}\right), 0.82\left(3 \mathrm{H}, \mathrm{s}, 18-\mathrm{H}_{3}\right), 5.27$ $\left(1 \mathrm{H}, \mathrm{ddd}, J_{4,3}=9.5, J_{4,5 \alpha}=4.5, J_{4,2 \alpha}=2.5,4-\mathrm{H}\right), 5.54(1 \mathrm{H}$, ddd, $\left.J_{3,4}=9.5, J_{3,2 \beta}=6.1, J_{3,2 \alpha}=3.1,3-\mathrm{H}\right), 10.04(1 \mathrm{H}, \mathrm{s}, \mathrm{NOH}) ;{ }^{13} \mathrm{C} \mathrm{NMR}$ (75.6 MHz, DMSO- $d_{6}$ ) $\delta: 11.7$ (C-19), 17.3 (C-18), 20.2, 22.7, 23.0, 24.7, 26.8, 31.0, 33.5, 34.3, 34.5, 34.6, 43.3, 45.3 (C-5), 52.9, 53.5, 125.3 (C-3), 131.0 (C-4), 167.9 (C-17); ESI m/z $288.2(\mathrm{M}+\mathrm{H}$, $100 \%)$.

\section{7. $3 \alpha, 4 \alpha$-Epoxy-5 $\alpha$-androstan-17-one oxime (4d)}

To a solution of $3 \alpha, 4 \alpha$-epoxy- $5 \alpha$-androstane-17-one $4 \mathrm{a}$ (100 $\mathrm{mg}, 0.35 \mathrm{mmol})$ in methanol $(7.0 \mathrm{ml})$, hydroxylamine hydrochloride $\left(30.3 \mathrm{mg}, 0.44 \mathrm{mmol}\right.$ ) and $\mathrm{CH}_{3} \mathrm{COONa} \cdot 3 \mathrm{H}_{2} \mathrm{O}$ $(59.5 \mathrm{mg}, 0.44 \mathrm{mmol})$ were added. The reaction was stirred at $40^{\circ} \mathrm{C}$ for $5 \mathrm{~h}$ until all the starting material has been consumed. After water addition $(50 \mathrm{ml})$ the methanol was evaporated and the aqueous phase was extracted with methylene chloride $(100 \mathrm{ml})$. The organic layer was then washed with $\mathrm{NaHCO}_{3}$ $10 \%(2 \times 50 \mathrm{ml})$, water $(3 \times 100 \mathrm{ml})$, dried over $\mathrm{MgSO}_{4}$, filtered and evaporated to dryness yielding the pure compound $4 \mathrm{~d}$

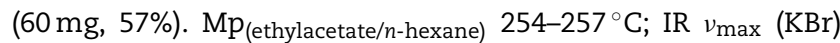
$\mathrm{cm}^{-1}: 3389(\mathrm{O}-\mathrm{H}),{ }^{1} \mathrm{H}$ NMR $\left(300 \mathrm{MHz}, \mathrm{DMSO}-d_{6}\right) \delta: 0.74(3 \mathrm{H}$, s, $\left.19-\mathrm{H}_{3}\right), 0.80\left(3 \mathrm{H}, \mathrm{s}, 18-\mathrm{H}_{3}\right), 2.60\left(1 \mathrm{H}, \mathrm{d}, J_{4 \beta, 3 \beta}=4.0,4 \beta-\mathrm{H}\right)$, $3.09\left(1 \mathrm{H}, \mathrm{dd}, J_{3 \beta, 4 \beta}=4.0, J_{3 \beta, 2 \mathrm{H}}=2.0,3 \beta-\mathrm{H}\right), 10.04(1 \mathrm{H}, \mathrm{s}, \mathrm{NOH})$; ${ }^{13} \mathrm{C}$ NMR (75.6 MHz, DMSO-d $\left.d_{6}\right) \delta: 13.1$ (C-19), 17.3 (C-18), $20.5,20.9,22.7,24.8,26.2,30.0,31.0,33.8,34.2,34.3,43.2$, 46.5, 51.1, 52.3, 53.3, 54.6, 167.9 (C-17); ESI $\mathrm{m} / \mathrm{z} 304.2(\mathrm{M}+\mathrm{H}$, $100 \%)$.

\subsection{Preparation of placental microsomes}

Placental microsomes were obtained as described by Yoshida and Osawa [16], with some modifications. Human placentas, obtained after delivery from a local hospital were placed in cold $67 \mathrm{mM}$ potassium phosphate buffer ( $\mathrm{pH} 7.4$ ) containing $1 \% \mathrm{KCl}$. The cotyledon tissue was separated and homogenized in a Polytron homogenizer with $67 \mathrm{mM}$ potassium phosphate buffer ( $\mathrm{pH} 7.4$ ) containing $0.25 \mathrm{M}$ sucrose and $0.5 \mathrm{mM}$ dithiothreitol (DTT, 1:1, w/v). The homogenate was centrifuged at $5000 \times g$ for $30 \mathrm{~min}$. The supernatant was centrifuged twice at $20,000 \times \mathrm{g}$ for $30 \mathrm{~min}$ and at $54,000 \times \mathrm{g}$ for $45 \mathrm{~min}$ to yield a microsomal pellet. The microsomes were washed and ressuspended in $67 \mathrm{mM}$ potassium phosphate buffer ( $\mathrm{pH}$ 7.4) containing $0.25 \mathrm{M}$ sucrose, $20 \%$ glycerol, and $0.5 \mathrm{mM} \mathrm{DTT}$ and stored at $-80^{\circ} \mathrm{C}$. All procedures were carried out at $0-5^{\circ} \mathrm{C}$. Protein content was estimated by the Bio-Rad protein assay (Bio-Rad Labs, Munich, Germany) using bovine serum albumin (BSA) as standard.

\subsection{Aromatase assay procedure}

Aromatase activity was measured according to Thompson and Siiteri [17], and Heidrich et al. [18], by measuring the ${ }^{3} \mathrm{H}_{2} \mathrm{O}$ released from $\left[1 \beta-{ }^{3} \mathrm{H}\right]$ androstenedione, which was purchased from PerkinElmer Life Sciences (Boston, MA, USA), during the aromatization process. All tested compounds were dissolved in DMSO and diluted in $67 \mathrm{mM}$ potassium phosphate buffer ( $\mathrm{pH}$ 7.4). Briefly, for the screening assay, the reaction mixture $(1 \mathrm{ml})$ contained $20 \mu \mathrm{g}$ of protein of the microsomes, $40 \mathrm{nM}$ of $\left[1 \beta^{-3} \mathrm{H}\right]$ androstenedione $(1 \mu \mathrm{Ci})$ and $2 \mu \mathrm{M}$ of each of the inhibitors. Aminoglutethymide (AG) and formestane (4-OHA) were used as control at $2 \mu \mathrm{M}$ and $0.5 \mu \mathrm{M}$, respectively. For the $\mathrm{IC}_{50}$ assay, the reaction mixture $(1 \mathrm{ml})$ contained $20 \mu \mathrm{g}$ of protein, $200 \mathrm{nM}$ of $\left[1 \beta^{-3} \mathrm{H}\right]$ androstenedione $(1 \mu \mathrm{Ci})$, and different concentrations of the inhibitors under study in $67 \mathrm{mM}$ potassium phosphate ( $\mathrm{pH}$ 7.4). The aromatase-catalyzed reaction was initiated by the addition of reduced nicotinamide adenine dinucleotide phosphate (NADPH, $150 \mu \mathrm{M})$, and incubations were performed at $37^{\circ} \mathrm{C}$ for $15 \mathrm{~min}$. However, to minimize the time-dependent loss of the initial aromatization rate, $5 \mathrm{~min}$ incubation time was used for the kinetic studies. The reaction was terminated by addition of $250 \mu$ l of $20 \%$ trichloroacetic acid. The mixture was transferred to microcentrifuge tubes containing a charcoal-dextran pellet, vortexed and incubated for $1 \mathrm{~h}$. After centrifugation at $14,000 \times g$ for $10 \mathrm{~min}$, the supernatants were transferred to new charcoal-dextran pellets, incubated for $10 \mathrm{~min}$ and subsequently pelleted by a new centrifugation cycle. The supernatant containing the tritiated water product was mixed with a liquid scintillation cocktail from ICN Radiochemicals (Irvine, CA, USA) and counted in a liquid scintillation counter (LS-6500, Beckman Coulter, Inc., Fullerton, CA). All experiments were carried out in triplicate.

\section{Results \\ 3.1. Chemistry}

Androstenedione 2 was prepared through oxidation of testosterone 1 (Scheme 1) with Jones Reagent and was, as expected, the only product formed in $98 \%$ yield. Clemmensen type reduction of 2 with zinc powder in acetic acid gave a mixture of $5 \alpha$ - and $5 \beta$-epimers from which the $5 \alpha$-epimer $3 a$ was isolated by crystallization in $60 \%$ yield [11]. Borohydride reduction of $3 \mathrm{a}$ in methanol yielded, after work-up, $89 \%$ of the steroidal alcohol $3 \mathrm{~b}$. Acetylation of $3 \mathrm{~b}$ with acetic anhydride in pyridine gave the acetyl derivative $3 \mathrm{c}$ in $87 \%$ yield. Treatment of $3 \mathrm{a}, 3 \mathrm{~b}$ and $3 \mathrm{c}$, in dichloromethane, with performic acid yielded the epoxide derivative $4 a, 4 b$ and $4 \mathrm{c}$ in $96 \%, 93 \%$ and $92 \%$, respectively. Reaction of $3 \mathrm{a}$ and 4a with hydroxylamine hydrochloride and sodium acetate in methanol gave the oxime derivatives $3 \mathrm{~d}$ and $4 \mathrm{~d}$ with, respectively, $84 \%$ and $57 \%$ yield. X-ray studies by single crystal difractometry revealed, unequivocally, the $E$ conformation of the hydroxyimine group of $3 \mathrm{~d}$ and $4 \mathrm{~d}$ (unpublished data). 


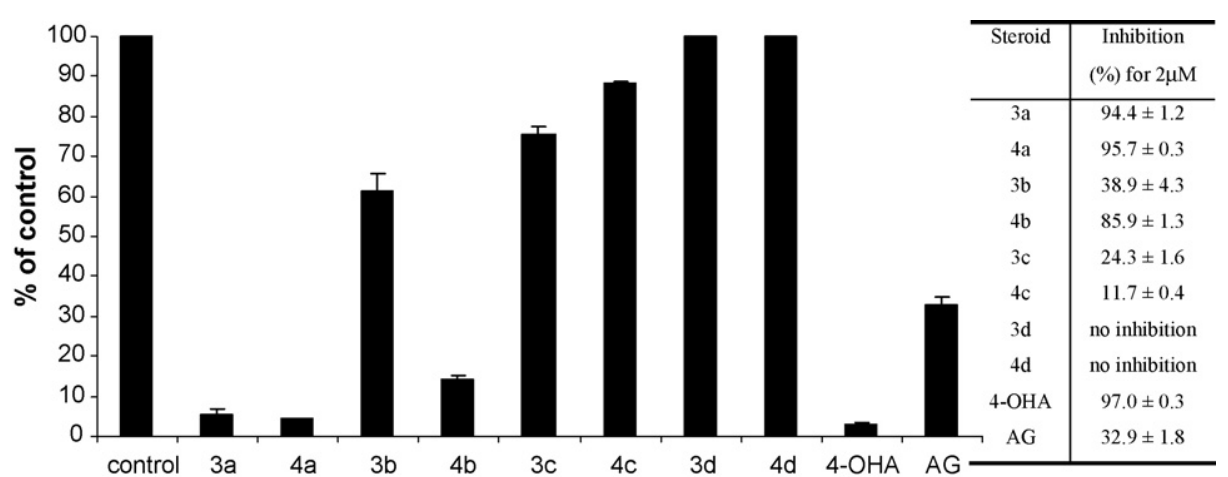

Fig. 2 - Aromatase inhibition for steroids $3 \mathrm{a}-\mathrm{d}$ and $4 \mathrm{a}-\mathrm{d}$. Concentrations of $40 \mathrm{nM}\left[1 \beta-{ }^{3} \mathrm{H}\right]$ androstenedione, $20 \mu \mathrm{g}$ protein from human placental microsomes, $2 \mu \mathrm{M}$ of the compounds and $15 \mathrm{~min}$ incubation were used. Results were normalized against a control treatment with vehicle and are the mean of at least three independent experiments done in triplicate. Formestane (4-OHA) and aminoglutethymide (AG) were used as reference substances.

\subsection{Biochemical properties}

Inhibition of aromatase by $3 a, 4 a$ and their respective $D$ ring modified derivatives $3 b-3 d$ and $4 b-4 d$ was evaluated in placental microsomes according to the Thompson and Siiteri method [17]. A screening assay was performed and the results are shown as percentage of inhibition for all compounds at $2 \mu \mathrm{M}$ relative to an assay in the absence of the inhibitor (Fig. 2). To study the range of inhibitory activities for the compounds under evaluation, the well-known aromatase inhibitors formestane (4-OHA) and aminoglutethymide (AG), the first AI approved by FDA, were used as reference compounds, showing $97.0 \% \pm 0.3$ and $32.9 \% \pm 1.8$ inhibition, respectively.

Among the C-17 derivatives of the ring-A epoxide series, compound $4 \mathrm{a}$ showed to be the most efficient steroid in inhibiting the enzyme $(95.7 \% \pm 0.3)$. When a hydroxyl group substituted the C-17 carbonyl group, as in $4 \mathrm{~b}$, the capacity to inhibit aromatase decreased to $85.9 \% \pm 1.3$. However, a more marked reduction of aromatase inhibitory activity was observed $(11.7 \% \pm 0.4)$ when the acetyl group, replaced the original carbonyl group, as in 4c. The replacement of the carbonyl group by a hydroxyimine group, as in $4 \mathrm{~d}$, resulted in a total incapacity to inhibit aromatase. Compound $3 \mathrm{a}$, the lead steroid of the ring-A olefin series, showed $94.4 \% \pm 1.2$ of aromatase inhibition. Substitution of C-17 carbonyl group by the hydroxyl, acetyl and hydroxyimine groups yielding compounds $3 b, 3 c$ and $3 d$ showed, respectively, $38.9 \% \pm 4.3$, $24.3 \% \pm 1.6$ and no inhibitory capacity.

The $\mathrm{IC}_{50}$ determined for inhibitor $4 \mathrm{~b}$ was $6.5 \mu \mathrm{M}$, whereas inhibitor $3 \mathrm{~b}$ at $30 \mu \mathrm{M}$ could not reach $50 \%$ of inhibition (Table 1). Inhibitor $4 \mathrm{~b}$ showed higher aromatase inhibitory activity than AG $\left(\mathrm{IC}_{50}=9.0 \mu \mathrm{M}\right)$, but lower than 4-OHA $\left(\mathrm{IC}_{50}=42 \mathrm{nM}\right)$ while $3 \mathrm{~b}$ was less efficient, in both cases. Inhibition kinetic studies for the most potent inhibitor (4b) were additionally performed using human placental microsomes. The type of binding to the active site of aromatase and the apparent inhibition constant $\left(\mathrm{K}_{\mathrm{i}}\right)$ were determined. This steroid $4 \mathrm{~b}$ revealed to be a competitive inhibitor, as shown in a Lineweaver-Burk plot in Fig. 3. The $K_{i}$, obtained by a Dixon plot, was $4.5 \mu \mathrm{M}$ (Fig. 4).

\section{Discussion}

According to our previous study [11], steroids $3 \mathrm{a}$ and $4 \mathrm{a}$ revealed to be strong aromatase inhibitors with an $\mathrm{IC}_{50}$ of $0.225 \mu \mathrm{M}$ and $0.145 \mu \mathrm{M}$ and $\mathrm{a} K_{\mathrm{i}}$ of $0.050 \mu \mathrm{M}$ and $0.038 \mu \mathrm{M}$, respectively. Androstenedione, the natural substrate of the enzyme, showed a $K_{m}$ of $0.0575 \mu \mathrm{M}$. These two compounds

Table 1 - In vitro aromatase inhibition

\begin{tabular}{lclll} 
Inhibitor & $\mathrm{IC}_{50}{ }^{\mathrm{a}}(\mu \mathrm{M})$ & $\mathrm{K}_{\mathrm{i}}^{\mathrm{b}}(\mu \mathrm{M})$ & Type of inhibition & Rel affinity $\left(K_{\mathrm{m}} / K_{\mathrm{i}}\right)$ \\
\hline 3a & $0.225 \pm 0.012$ & 0.050 & Competitive & 1.15 \\
4a & $0.145 \pm 0.002$ & 0.038 & Competitive & 1.51 \\
3b & 30 & n.d. & n.d. & n.d. \\
4b & $6.5 \pm 0.49$ & 4.5 & Competitive & 0.013 \\
4-OHA & $0.042 \pm 0.001$ & n.d. & n.d. & n.d. \\
AG & $9.0 \pm 0.24$ & n.d. & n.d. & n.d.
\end{tabular}

The experiments were done in triplicate. The results represent the mean \pm S.E. of three different experiments.

n.d.: not determined.

a Concentrations of $200 \mathrm{nM}\left[1 \beta^{-3} \mathrm{H}\right]$ androstenedione and $20 \mu \mathrm{g}$ of protein from human placental microsomes.

b Apparent inhibition constants $\left(K_{i}\right)$ were obtained by Dixon Plot.

Inhibition type was based on analysis of Lineweaver-Burk plot. 


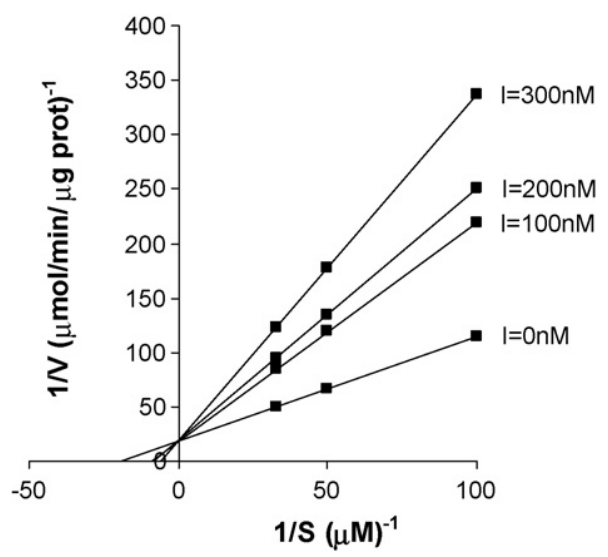

Fig. 3 - Lineweaver-Burk plot of inhibition of human placental aromatase by $4 \mathrm{~b}$ with androstenedione as substrate. Androstenedione was incubated in a variable range of concentrations with the microsomal enzyme preparations and inhibitor $4 \mathrm{~b}$ at different concentrations $(0$, $100,200$ and $300 \mathrm{nM})$. Each point represents the mean of three independent determinations \pm standard error.

bind the enzyme in a competitive type-manner and with a slightly higher affinity than androstenedione (respectively, 1.15 and 1.51 times more for inhibitors $3 a$ and $4 a$ ) proving that the C-3 carbonyl group, present in the natural substrate of the enzyme and in many other aromatase inhibitors, is not essential for the enzyme-inhibitor interaction and inhibition. However, the results obtained in the present work show that unlike C-3 carbonyl, the C-17 carbonyl group present in the $5 \alpha$-androst- 3 -ene and $3 \alpha, 4 \alpha$-epoxy- $5 \alpha$-androstane derivatives seems to be fundamental to reach maximum aromatase inhibitory activity. Modification of C-17 carbonyl group of 3a, such as reduction to a $17 \beta$-hydroxyl group (3b), dramatically reduced the capacity of aromatase inhibition. The same type of chemical transformation performed in inhibitor 4 a to give $4 \mathrm{~b}$ showed only a modest reduction of aromatase inhibitory

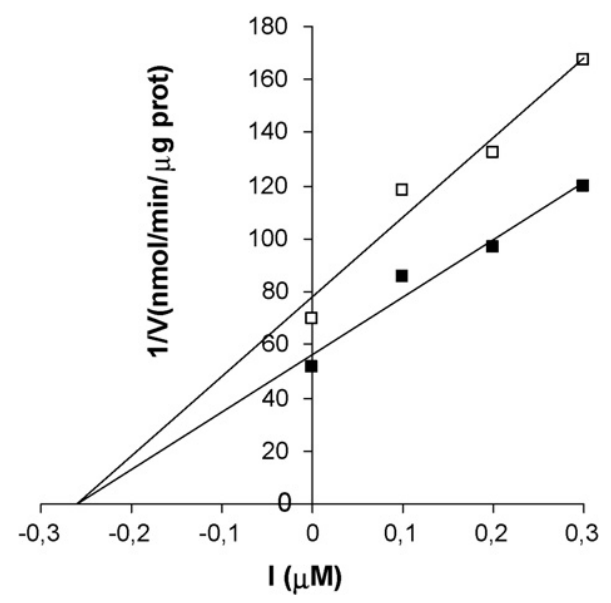

Fig. 4 - Dixon plots to determine the apparent inhibition constant $\left(K_{i}\right)$ for inhibitor $4 \mathrm{~b}$. Microsomal proteins $(20 \mu \mathrm{g})$ were incubated with inhibitor $4 \mathrm{~b}(100,200$ and $300 \mathrm{nM})$ and androstenedione substrate was used at $10 \mathrm{nM}(\square)$ and $20 \mathrm{nM}(\square)$. activity, but a considerable decrease in affinity to aromatase, from $K_{i}=0.038 \mu \mathrm{M}$ in $4 \mathrm{a}$ to $K_{\mathrm{i}}=4.5 \mu \mathrm{M}$ in $4 \mathrm{~b}$. In fact, the substitution of a carbonyl group, which is a proton acceptor by a hydroxyl group, which is a proton donor, could interfere with the anchoring of the D-ring by the hydrophilic residue of the active site, which is believed to establish a hydrogen bond with C-17 carbonyl group. The same behavior was observed by Numazawa et al. with 3-deoxyandrost-4-ene steroid analogs [13]. Furthermore, according to a recent model of the active site of aromatase [19], and a new clamping mechanism of substrate binding to the active site of aromatase [20], the steroidal D-ring must be anchored by Van der Walls forces through hydrophobic residues, such as I133 and F134, in the B'-C loop of aromatase binding pocket. These residues are described as providing hydrophobic interactions with steroid inhibitors, stabilizing them in the active site. We believe that replacement of the C-17 carbonyl group in the D-ring of $3 a / 4 a$ by the more hydrophilic hydroxyl group, as in $3 b / 4 b$, may result in destabilization of the enzyme-compound interaction, decreasing its inhibitory activity. The better aromatase inhibitory activity observed for $4 b$ relatively to $3 b$ could be attributed to the presence of a shared oxygen atom by the C-3 and C-4, in $4 \mathrm{~b}$. In fact, it is accepted that the C-3 carbonyl group of androstenedione is involved in its binding to the active site of aromatase $[21,22]$. The C-3, C-4 oxygen atom of $4 \mathrm{~b}$ could play a similar role of that of $\mathrm{C}-3$ oxygen atom of androstenedione.

The introduction of an acetyl group at C-17 instead of the carbonyl group, as in $3 \mathrm{c}$ and $4 \mathrm{c}$, leads to a more dramatic reduction of aromatase inhibitory activity. In this case, the acetyl group is, as the carbonyl group, proton acceptor but being also a bulky group, may cause steric hindrance at the enzyme active site, resulting in the observed loss of activity. Here, the C-3, C-4 oxygen atom of 4c, does not benefit the binding to aromatase. In this case, the C-17 bulky group seems to be determinant.

Finally, the substitution of the original carbonyl group by the hydroxyimine group as in $3 \mathrm{~d}$ and $4 \mathrm{~d}$ leads to compounds with no aromatase inhibitory activity. The hydroxyimine group is simultaneously proton donor and proton acceptor and therefore allows the establishment of hydrogen bonds with the hydrophilic residue of the aromatase active site. Nevertheless, the additional presence of a proton donor group, which confers hydrophylicity, and the steric hindrance of the hydroxyimine group may imply conformational conflicts with the enzyme active site resulting in the complete absence of aromatase inhibitory activity.

In summary, as long the steroidal five-membered $\mathrm{D}$ ring is present, a C-17 carbonyl group in $5 \alpha$-androst-3-ene and $3 \alpha, 4 \alpha$-epoxy- $5 \alpha$-androstane series is essential to reach maximum aromatase inhibitory activity. Additionally, these compounds should not contain bulky groups in the C-17 position in order to have activity. The differences in aromatase inhibitory activity of $3 \mathrm{~b}$ and $4 \mathrm{~b}$ suggest that the binding geometry of the 3-deoxysteroid ( $3 b$ ) to the active site of aromatase would be different from that of the 3,4-epoxysteroid (4b). This is pointed out by site-directed mutagenesis and computer-assisted protein-ligand docking studies on 3a and 4a (unpublished results). The presence of an oxygen atom in the 3,4 position of $4 \mathrm{~b}$ seems to benefit the binding to the active site. The results obtained in this study along with those 
already reported [11-13], particularly those where the C-17 carbonyl group was removed resulting molecules with strong activity [12], lead to the major conclusion that the lack of one of the two C-3 or C-17 carbonyl groups in steroidal aromatase inhibitors does not affects significantly the aromatase inhibitory activity but the lack of both affects dramatically the referred activity. This statement is reinforced by the fact that testosterone (1), which has a C-3 carbonyl and C-17 hydroxyl groups, is as good a substrate for aromatase as is androstenedione (2), which has the two C-3 and C-17 carbonyl groups. It is expected that the results of this study could help in the future design of new steroidal aromatase inhibitors as well as in the establishment of SAR and QSAR for this kind of compounds.

\section{Acknowledgments}

We thank Dr. Isabel Campos of São João Hospital, Oporto, for kindly supplying human term placenta. M. Cepa is a recipient of a Ph.D. grant of Fundação para a Ciência e Tecnologia (FCT) (SFRH/BD/10736/2002).

\section{Appendix A. Supplementary data}

Supplementary data associated with this article can be found, in the online version, at doi:10.1016/j.steroids.2008.07.001.

\section{R E F E R E C E S}

[1] Cuzick J, Wang DY, Bulbrook RD. The prevention of breast cancer. Lancet 1986;8472:83-6.

[2] Winer EP, Hudis C, Burstein HJ, Wolff AC, Pritchard KI, Ingle $\mathrm{JN}$, et al. American Society of Clinical Oncology technology assessment on the use of aromatase inhibitors as adjuvant therapy for postmenopausal women with hormone receptor-positive breast cancer: status report 2004. J Clin Oncol 2005;23:619-29.

[3] Perez EA. Appraising adjuvant aromatase inhibitor therapy. Oncologist 2006;11:1058-69.

[4] Thuerlimann B, Koeberle D, Senn H. Guidelines for the adjuvant treatment of postmenopausal women with endocrine-responsive breast cancer: Past, present and future recommendations. Eur J Cancer 2007;43:46-52.

[5] Jordan VC, Brodie A. Development and evolution of therapies targeted to the estrogen receptor for the treatment and prevention of breast cancer. Steroids 2007;72:7-25.

[6] Howell A, Buzdar A. Are aromatase inhibitors superior to antiestrogens? J Steroid Biochem Mol Biol 2005;93: 237-47.

[7] O'Reillly JM, Brueggmeier RW. Development of steroidal and non-steroidal inhibitors of aromatase for the treatment of hormone-dependent breast cancer. Curr Med Chem 1996;3:11-22.

[8] Banting L, Nicholls PJ, Shaw MA, Smith HJ. Recent developments in aromatase inhibition as a potential treatment for estrogen-dependent breast cancer. Prog Med Chem 1989;26:253-98.

[9] Banting L. Inhibition of aromatase. Prog Med Chem 1996;33:147-84.

[10] Miller WR, Anderson TJ, Jack WJL. Relationship between tumor aromatase activity, tumor characteristics and response to therapy. J Steroid Biochem Mol Biol 1990;37:537-48.

[11] Cepa MMDS, Tavares da Silva EJ, Correia-da-Silva G, Roleira FMF, Teixeira NAA. Structure-activity relationships of new A,D-ring modified steroids as aromatase inhibitors: Design, synthesis and biological activity evaluation. J Med Chem 2005;48:6379-85.

[12] Sherwin PF, McMullan PC, Covey DF. Effects of steroid D-ring modification on suicide inactivation and competitive inhibition of aromatase by analogues of androsta-1,4-diene-3,17-dione. J Med Chem 1989;32:651-8.

[13] Numazawa M, Kamiyama T, Tachibana M, Oshibe MJ. Synthesis and structure-activity relationships of 6-substituted androst-4-ene analogs as aromatase inhibitors. J Med Chem 1996;39:2245-52.

[14] Rasmusson GH. In: Fried JH, Edwards JA, editors. Organic reactions in steroid chemistry, vol. I. New York: Van Nostrand-Reinhold; 1972. p. 222-64.

[15] McKenna J, Norymbersky JK, Stubbs RD. Partial reduction of steroid hormones and related substances. Part III. The reaction of $\alpha, \beta$-unsaturated ketones with zinc in acetic acid. J Chem Soc 1959:2502-9.

[16] Yoshida N, Osawa Y. Purification of human placental aromatase cytocrome P-450 with monoclonal antibody and its characterization. Biochemistry 1991;30:3003-10.

[17] Thompson EA, Siiteri PK. Utilization of oxygen and reduced nicotinamide adenine dinucleotide phosphate by human placental microsomes during aromatization of androstenedione. Biol Chem 1974;249:53-64.

[18] Heidrich D, Steckelbroeck S, Klingmuller D. Inhibiton of human cytocrome P-450 aromatase activity by butylins. Steroids 2001;66:763-9.

[19] Favia AD, Cavalli A, Masetti M, Carotti A, Recanatini M. Three-dimensional modal of the human aromatase enzyme and density functional parameterization of the iron-containing protoporphyrin IX for a molecular dynamics study of heme-cysteinato cytochromes. Proteins 2006;62:1074-87.

[20] Hong Y, Yu B, Sherman M, Yuan YC, Zhou D, Chen S. Molecular basis for the aromatization reaction and exemestane-mediated irreversible inhibition of human aromatase. Mol Endocrinol 2007;21:401-14.

[21] Oh SS, Robinson CH. Mechanism of human placental aromatase: a new active site model. J Steroid Biochem Mol Biol 1993;44:389-97.

[22] Graham-Lorence S, Amarneh B, White RE, Peterson JA, Simpson ER. A three-dimensional model of aromatase cytochrome P450. Protein Sci 1995;4:1065-80. 